Paedagogia Christiana

2/30 (2012) - ISSN 1505-6872

Agnieszka Watęga*

Toruń

\title{
Obraz edukacji religijnej w polskich podręcznikach historii wychowania XIX i początków XX wieku
}

Problematyka edukacji religijnej od wielu lat budzi zainteresowanie licznych badaczy, w tym także historyków wychowania. Świadczy o tym znaczna liczba publikacji poświęcona tym zagadnieniom ${ }^{1}$. W wydanych dotychczas pracach nie uwzględniano jednak podręczników historii wychowania jako źródeł do badań nad tą problematykąa ${ }^{2}$ Warto się do nich odwołać pamiętając, że mogły one kształtować świadomość i poglądy wielu przyszłych nauczycieli i wychowawców, i to w okresie niezwykle trudnym dla Polaków - w dobie zaborów i podczas odbudowywania własnej państwowości w latach II Rzeczypospolitej. Prezentowany artykuł stanowi próbę odpowiedzi na pytanie, jaki obraz edukacji religijnej przekazywano w pierwszych tego typu opracowaniach z II połowy XIX i początków XX wieku.

* Dr hab. Agnieszka Wałęga, adiunkt w Katedrze Pedagogiki Wydziału Nauk Pedagogicznych UMK w Toruniu.

${ }^{1}$ Szczególne zainteresowanie budzi zwłaszcza działalność edukacyjna i wychowawcza jezuitów oraz pijarów: I. Stasiewicz-Jasiukowa (red.), Wkład pijarów do nauki i kultury w Polsce XVII-XIX wieku, Kraków 1993; I. Stasiewicz-Jasiukowa (red.), Wkład jezuitów do nauki i kultury w Rzeczypospolitej Obojga Narodów i pod zaborami, Kraków 2004; J. Kochanowicz, Geneza, organizacja i działalność jezuickich burs muzycznych, Kraków 2002; L. Piechnik, Powstanie i rozwój jezuickiej „,Ratio studiorum” (1548-1599), Kraków 2003; K. Puchowski, Jezuickie kolegia szlacheckie Rzeczypospolitej Obojga Narodów, Gdańsk 2007.

${ }^{2}$ Na temat podręczników historii wychowania jako źródeł historycznych szerzej: W. Szulakiewicz, Podręczniki historii wychowania jako źródła historyczne ,, adresowane”, w: tenże (red.), Źródła w badaniach naukowych historii edukacji, Toruń 2003, s. 109-126. 
Odtworzenie sygnalizowanego w tytule obrazu wymaga uwzględnienia kilku problemów. Dlatego też w artykule podjęto próbę odpowiedzi na następujące pytania: W jakim zakresie, chronologicznym i tematycznym, najstarsze polskie podręczniki historii wychowania uwzględniają problematykę edukacji religijnej?; Jaki zasób wiedzy na ten temat, i w jakiej formie, przekazuja poszczególni autorzy?; Jaki jest ich stosunek wobec tych zagadnień? Odpowiedzi na powyższe pytania będa poszukiwane w wybranych najstarszych polskich podręcznikach historii wychowania wydanych w latach zaborów i II Rzeczypospolitej. Są to między innymi opracowania takich autorów jak Edward Hückel ${ }^{3}$, Antoni Łuczkiewicz ${ }^{4}$, Maria Bielska ${ }^{5}$, Władysław Seredyński ${ }^{6}$, Franciszek Majchrowicz ${ }^{7}$, Józef Bielenin ${ }^{8}$, Jan Tadeusz Peche ${ }^{9}$ oraz Stanisław Kot ${ }^{10}$.

Na wstępie należy oczywiście zaznaczyć, że na obraz edukacji religijnej zawarty w podręcznikach historii wychowania wpływało wiele czynników. Istotne znacznie miało merytoryczne przygotowanie ich autorów do podejmowania tej problematyki. Trzeba w tym miejscu wspomnieć, że w gronie twórców analizowanych tutaj publikacji spotykamy kilku duchownych z bogatym doświadczeniem dydaktycznym, którzy prowadzili zajęcia z histo-

${ }^{3}$ E. Hückel, Rys pedagogiki, Lwów 1868.

${ }^{4}$ A. Łuczkiewicz, Szkolnictwo na podstawie historycznego rozwoju i zasad wychowania podtug planu przepisanego dla seminariów nauczycielskich, Lwów 1872.

${ }^{5}$ M. Bielska, Historia pedagogii, Lwów 1890. Podręcznik ten został ponownie wydany w roku 1899.

${ }^{6}$ W. Seredyński, Rys dziejów wychowania w biografiach i szkicach ze szczególnym uwzględnieniem szkoty ludowej w Austrii $i$ w Polsce dla użytku seminariów nauczycielskich polskich, Tarnów 1891.

${ }^{7}$ F. Majchrowicz, Historia pedagogii ze szczególnym uwzględnieniem dziejów wychowania i szkót w Polsce, Warszawa 1922. Podręcznik F. Majchrowicza miał łącznie 5 wydań. Trzy pierwsze wydania ukazały się pt. Historia pedagogii dla użytku seminariów nauczycielskich i nauki prywatnej, wyd. I, Drohobycz 1901; wyd. II, Lwów 1907; wyd. III (dwutomowe) Lwów 1920; wyd. V również pod zmienionym tytułem ukazało się w Warszawie w roku 1924.

8 J. Bielenin, Historia pedagogiki. Wykłady, Kraków 1917 (rękopis w zbiorach Biblioteki Jagiellońskiej w Krakowie); tenże, Szkoły i wychowanie w Polsce do końca XVIII wieku. Praca dla użytku uczniów i uczennic seminaryjnych oraz kursów wydziałowych, w: Sprawozdanie Dyrekcji c.k. Męskiego Seminarium Nauczycielskiego w Krakowie za lata szkolne 1907/8; 1908/9, 1909/10, Kraków 1910, s. 7-70.

9 J. T. Peche, Pedagogika. Podręcznik szkolny w zakresie nauczania średniego. Opracowana podtug najnowszych wskazań wychowawczych, wyd. II, Poznań 1922 (wyd. I ukazało się w roku 1918 w Warszawie).

${ }^{10}$ S. Kot, Historia wychowania. Zarys podręcznikowy, Warszawa 1924; tenże, Zarys dziejów wychowania jako funkcji społecznej, w: Encyklopedia Wychowania, t. I, Warszawa 1934, s. 569-660. (Zarys ten miał także osobne odbicia, które ukazały się w roku 1936 oraz ponownie w Warszawie w roku 1947). 
rii wychowania a następnie opracowywali podręczniki tego przedmiotu ${ }^{11}$. Równie ważną rolę pełniła grupa odbiorców - uczniów seminariów nauczycielskich oraz studentów - to do ich potrzeb i możliwości percepcyjnych dostosowywano bowiem zakres i sposób przekazu treści. Nie bez znaczenia są także daty opublikowania poszczególnych podręczników. Wyraźnie wskazują one na istniejący wówczas stan wiedzy na temat edukacji religijnej ${ }^{12}$.

Jaki zatem obraz edukacji religijnej wyłania się z analizowanych opracowań? W najstarszych polskich podręcznikach historii wychowania szeroko prezentowano wychowanie u ludów starożytnego Wschodu. Ukazywano je poprzez pryzmat ich wierzeń religijnych. Częściowo wiązało się to z wzorowaniem się autorów na Chowannie Bronisława Ferdynanda Trentowskiego. Filozof ten uważał bowiem, że „Chcąc poznać naród jaki, daleki od nas i dlatego obcy nam zupełnie pod względem charakteru, a szczególniej wychowania, najlepsza zastanowić się nad jego religią"13. W jego ocenie szczególne znaczenie miało to właśnie w odniesieniu do ludów starożytnych, dla których religia stanowiła fundament procesów wychowawczych ${ }^{14}$. Wyraźnie nawiązywał do tego chociażby Władysław Seredyński, podkreślając w swoim podręczniku, że skoro u ludów Wschodu wszelkie obowiązujące zasady i urządzenia społeczne wypływały z nakazów wyznawanej przez dany naród religii, to także kwestie wychowawcze należy rozpatrywać w kontekście dogmatów religijnych i związanych $\mathrm{z}$ nimi zasad moralnych ${ }^{15}$. Przykładowo z religii perskiej opartej na odwiecznej rywalizacji dobra ze złem wypływały, jego zdaniem, ideały wojowniczości i bohaterstwa zaszczepiane tamtejszej młodzieży w procesie wychowania ${ }^{16}$.

${ }^{11}$ Byli to ks. Józef Bielenin i ks. Jan Tadeusz Peche. Szerzej na temat autorów podręczników historii wychowania: A. Wałęga, Autorzy polskich podręczników do historii wychowania XIX i I połowy XX wieku, „Acta Universitatis Nicolai Copernici, Pedagogika” XXIV (2009), s. $95-116$.

${ }^{12}$ Szerszych informacji na temat polskich podręczników historii wychowania dostarczają następujące publikacje: A. Meissner, Polskie podręczniki do historii wychowania, „Rozprawy z Dziejów Oświaty” XXXII (1989), s. 155-167; tenże, Polskie podręczniki do historii wychowania po II wojnie światowej, w: T. Gumuła, S. Majewski (red.), Historia wychowania w ksztatceniu nauczycieli. Tradycja i wspótczesność. Teoria i praktyka, Kielce 2005, s. 47-54; tenże, Podręczniki do historii wychowania, w: T. Pilch (red.), Encyklopedia Pedagogiczna XXI wieku, t. IV, Warszawa 2005, s. 477-480; A. Wałęga, Polskie podręczniki i wydawnictwa pomocnicze do historii wychowania okresu zaborów i II Rzeczypospolitej, Torun 2011.

${ }_{13}$ B. F. Trentowski, Chowanna czyli system pedagogiki narodowej jako umiejętności wychowania, nauki i oświaty, słowem wyksztatcenia naszej młodzieży, t. II, Wrocław-Warszawa-Kraków 1970, s. 415.

14 Tamże, s. 426, por. s. 457.

15 W. Seredyński, dz. cyt., s. 4.

16 Tamże, s. 12-14. 
Na kwestie te zwrócił uwagę także Stanisław Kot, który charakteryzując kultury wschodnie podkreślił rolę tradycji oraz „kultu świętych ksiag zaszczepianego przez wychowanie" w kształtowaniu młodego pokolenia. Jego zdaniem, wychowanie orientalne było wychowaniem teokratycznoreligijnym, szczególnie u Żydów, o których pisał: „Wyłączną treść kultury stanowiła religia [...] Jehowa objawił się Żydom w całym biegu ich historii narodowej, która przez to stała się ich mitologia, procesem wychowawczym dla narodu, wzorem dla jednostek" ${ }^{17}$. Podkreślał on rolę rabinów jako znawców Prawa (słowa Bożego) i obowiązek wychowywania dzieci według tego prawa. Zauważał też przejęcie przez chrześcijaństwo niektórych metod wychowawczych Żydów: oparcia kształcenia na tekstach świętych, dekalogu czy psałterzu, indywidualne zaznajamianie uczniów z zasadami wiary, przypisywanie rodzinie ważnych funkcji wychowawczych.

Uczniowie korzystający z najstarszych polskich podręczników historii wychowania otrzymywali zatem dość szeroki zakres wiadomości dotyczących religii starożytnego Wschodu oraz ich wpływu na ostateczny kształt wychowania i kształcenia przyjętego przez poszczególne ludy. Zdecydowanie mniej miejsca poświęcano tym kwestiom przy prezentacji starożytnej Grecji. Wielu autorów zaznaczało jedynie, że odmienne od wschodniego pojmowanie Bogów wpłynęło też na określenie odrębnych celów wychowania. Za charakterystyczne zjawisko uznać można wyrażanie pejoratywnych opinii dotyczących pedagogiki epoki starożytnej przez autorów reprezentujących duchowieństwo katolickie. Przykładowo ks. Józef Bielenin uczulał swoich czytelników na nieudolność świata pogańskiego na polu wychowania, konkludując: „Samobójstwo też i kult śmierci były ostatnim wyrazem pedagogiki starożytnego świata"18. Podsumowując te rozważania, należy zaznaczyć, że w wielu przypadkach w podręcznikach wskazywano właśnie na Boga chrześcijan jako najważniejszego wychowawcę rodu ludzkiego. Zaznaczano, że to Chrystus pierwszy zwrócił uwagę na znaczenie szacunku i miłości w stosunku do dzieci oraz docenił trud pracy wychowawców i nauczycieli.

Autorzy analizowanych tutaj podręczników często wskazywali na pozytywne zmiany, jakie w zakresie oświaty i wychowania wprowadziło chrześcijaństwo. Zaliczali do nich między innymi nowe zasady funkcjonowania rodziny - podniesienie pozycji kobiet czy wzajemne obowiązki dzieci i rodziców wobec siebie oraz propagowanie zasady równości wszystkich ludzi. W Historii pedagogii Marii Bielskiej spotykamy też wymowną uwagę dotycząca znaczenia żarliwości religijnej pierwszych chrześcijan: „Ewangelia,

17 S. Kot, Zarys, s. 582-583.

18 J. Bielenin, Historia, s. 87. 
głosząca prawdy nowe [...], która stwierdza swą naukę krwią tysięcy, którzy dla miłości prawdy w najstraszniejszych giną mękach, nauka taka musiała poruszać podstawy społeczeństwa, musiała odmieniać poglądy dotychczasowe o wychowaniu młodzieży"19.

W podręcznikach zazwyczaj przedstawiano ojców Kościoła oraz doceniano postawę tych chrześcijan, którzy potrafili łączyć wiedzę zawartą w pracach autorów pogańskich z przesłaniem Pisma Świętego. Ważne miejsce zajmował tam szczególnie św. Hieronim, przedstawiany głównie jako twórca wskazówek dotyczących edukacji kobiet, które wywarły znaczny wpływ na wychowanie dziewcząt w wiekach średnich. Z kolei św. Augustyn był ukazywany jako autor Wyznań, czyli pierwszego dzieła o charakterze psychologiczno-pedagogicznym, w którym harmonijnie połączono praktyczne doświadczenia życiowe z wiedzą teoretyczną. Podkreślano też znaczenie jego koncepcji nauczania, uwzględniającej koncentrację $\mathrm{i}$ indywidualne zdolności i możliwości intelektualne uczniów.

Wiele uwagi poświęcano zasługom zakonów benedyktynów dla oświaty. Krótko wspominano też o działalności dominikanów i franciszkanów na tym polu. Niektórzy autorzy, jak na przykład Władysław Seredyński, krzewienie przez kapłanów zasad nowej wiary uznawali za początki współczesnych szkół ludowych, przyznając ,że szkoła nowożytna jest córką i wychowanica Kościoła"20. Powszechne było także ukazywanie ogromnego wpływu Kościoła na rozwój szkół w Polsce oraz braku zainteresowania oświatą ze strony władzy świeckiej, która zajęta innymi sprawami kraju cedowała te obowiązki na duchownych i zakonników. Szczególnie wiele miejsca poświęcił tym kwestiom ks. Józef Bielenin, podkreślając działania podejmowane wówczas w celu podniesienia poziomu wykształcenia duchowieństwa ${ }^{21}$.

Próbę podsumowania efektów wychowania religijnego w średniowiecznej Polsce odnajdujemy między innymi w podręczniku Jana Tadeusza Peche. Pisał on na ten temat następująco:

Naród polski głęboko wierzący, w tym okresie szczególniej okazał się dbałym o wychowanie moralne i religijne swej młodzieży. Surowość obyczajów, praktyki religijne, poszanowanie i bezwzględne posłuszeństwo rodzicom i przełożonym były cechami epoki. Jeszcze demoralizujące wpływy zepsucia zachodniego nie doszły do Polski. Piękne charaktery i czyny bohaterskie obok licznych świętych z tego okresu w Polsce dowodzą, iż moralne zdrowie wraz

\footnotetext{
${ }^{19}$ M. Bielska, dz. cyt., s. 45.

${ }^{20}$ W. Seredyński, dz. cyt., s. 36.

${ }^{21}$ J. Bielenin, Szkoty, s. 18-19.
} 
z dążeniem do rozwoju państwowości, mogły już wtedy rokować piękną, promienną przyszłość naszej ojczyźnie ${ }^{22}$.

Autorzy podręczników często zaznaczali także, że choć oficjalnym językiem nauczania w średniowieczu była łacina, to nakaz wygłaszania kazań dla ludu w języku polskim wpływał także na większe zainteresowanie językiem ojczystym w szkołach. Przykładowo Stanisław Kot podkreślał zagrożenie germanizacyjne w szkolnictwie średniowiecznym oraz postawę Kościoła wobec tych problemów: „kierownictwo Kościoła polskiego staje na stanowisku narodowym i przepisuje klerykom kształconym w szkołach kościelnych znajomość języka polskiego"23.

W podręcznikach spotykamy także opinie dotyczące zalet scholastyki. Wyrażał je między innymi Władysław Seredyński oceniając, że: „Odrodzenie i humanizm tylko po przygotowawczej epoce scholastycznej mogły tak szeroko i powszechnie dźwignąć umysłowość człowieka"24.

Wiele uwagi poświęcano także reformacji oraz ocenie jej wpływu na wychowanie i szkolnictwo. Opinie poszczególnych autorów tych opracowań różniły się znacząco w tej kwestii. Niektórzy zamieszczali w podręcznikach jedynie pozytywne i bezkrytyczne opinie na ten temat. Zdarzały się jednak także oceny bardziej wyważone, w których uwzględniono negatywny wpływ reformacji na oświatę. Do zdecydowanych propagatorów koncepcji pozytywnego oddziaływania zachodzących wówczas przemian religijnych na pedagogikę z pewnością zaliczyć możemy Antoniego Łuczkiewicza. Twierdził on, że wpływ reformacji na wychowanie publiczne to przede wszystkim konkurencja w dziedzinie oświaty oraz wprowadzenie zmian do szkolnictwa katolickiego w wyniku działalności zakonu jezuitów ${ }^{25}$. O negatywnych aspektach reformacji wspominał natomiast Franciszek Majchrowicz, który przypominał o tendencyjnym prezentowaniu tych zagadnień przez pisarzy protestanckich. Swoim czytelnikom uświadamiał takie negatywne skutki początkowego etapu reformacji, jak upadek wielu szkół i ogólny chaos w dzie-

22 J. T. Peche, dz. cyt., s. 282.

23 S. Kot, Historia, s. 140.

${ }^{24}$ W. Seredyński, dz. cyt., s. 44. Uzasadniał to następująco: „Nadto zakłady scholastyczne nawet i w swoim czasie rachowały się z potrzebami natury ludzkiej. Kiedy duchowość człowieka w celach moralnych a kosztem sił fizycznych i umysłowej wszechstronności dźwignąć usiłowano, to urządzenia tego rodzaju, jak częste procesje i pielgrzymki w czasie uroczystości religijnych, połączone ze śpiewem chóralnym, dramatyczne produkcje (treści biblijnej) i liczne uroczystości szkolne połączone z ucztami wspólnymi, wpływały przecież na urozmaicenie umysłowych i fizycznych stosunków życia ludu i młodzieży”. Tamże.

${ }^{25}$ A. Łuczkiewicz, dz. cyt., s. 141-142. 
dzinie oświaty ${ }^{26}$. Negatywnie ten etap reformacji oceniał także Stanisław Kot, który zaznaczał, że zburzyła ona podstawy funkcjonowania prawnego i ekonomicznego oświaty oraz przekonała część społeczeństwa do rezygnacji z nauki ${ }^{27}$. Wyraźnie sygnalizował on także dalekosiężne skutki reformacji, która osłabiła pozycję Kościoła, ale jednocześnie nadała mu przywilej wychowywania społeczeństw katolickich poprzez zakony nauczające ${ }^{28}$.

Zdecydowanym krytykiem reformacji był natomiast Jan Tadeusz Peche. Zwracał on uwagę czytelników na to, że ,wszyscy [...] pedagogowie protestanccy w tej epoce, wynieśli swe poglądy ze szkół klasztornych i katolickich uniwersytetów humanistycznych, gdzie się kształcili”29. Wyraźnie też podkreślał, że pedagogika protestancka miała charakter wtórny. Jak argumentował:

W wielu wypadkach sam zresztą protestantyzm tylko naśladował współczesną lub dawniejszą działalność Kościoła, a już w szkolnictwie wiele dobrego z małymi zmianami zapożyczał od odradzającego się szkolnictwa katolickiego. Prawda, że i szkoły katolickie korzystały z pomysłów pedagogicznych innowierców - gdyż ulepszona metoda wychowawcza nie może być niczyją wyłączną własnością. Wszakże wcześniejszym jest ruch szkolny katolicki od protestanckiego ${ }^{30}$.

Spośród prowadzących wówczas działalność oświatową zakonów w podręcznikach szczególnie eksponowano jezuitów i pijarów. Stosunek poszczególnych autorów wobec pedagogii ignacjańskiej był niezwykle zróżnicowany. Na kartach podręczników odnajdujemy zarówno wyważone opinie, uwzględniające wady oraz zalety szkół jezuickich, jak i entuzjastyczne i jednoznacznie pozytywne oceny. Przykładowo Edward Hückel wysoko ocenił szkoły jezuickie. Także o samych jezuitach pisał niezwykle pochlebnie: „Jezuici byli znawcami ludzi, dlatego też i dobrymi pedagogami. Nie wchodząc w cele i środki tego towarzystwa, w ich zatargi z rządami i narodami, potrzeba oddać sprawiedliwość ich rozwojowi pedagogicznemu"31. Podobnie Antoni Łuczkiewicz, który zaznaczył popularność szkół jezuickich w Polsce i oceniał: „Zaprzeczyć nie można, że Jezuici gorliwie zajmowali się zaprowadzeniem szkół i ulepszeniem sposobu nauczania, a jeżeli metoda ich nie

\footnotetext{
26 F. Majchrowicz, dz. cyt., s. 90-91.

27 S. Kot, Historia, s. 166-167.

28 Tenże, Zarys, s. 611-612.

29 J. T. Peche, dz. cyt., s. 292.

30 Tamże, s. 294.

31 E. Hückel, dz. cyt., s. 24.
} 
była tak dobra jak dzisiejsza, to nie ich w tym wina"32. Do grona zdecydowanych zwolenników szkolnictwa i pedagogiki jezuickiej zaliczyć możemy z pewnością Władysława Serdyńskiego i Franciszka Majchrowicza. Podkreślali oni, że to właśnie jezuici ,utworzyli szkołę, która była arcydzie-

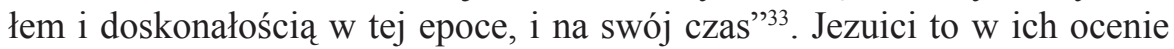
doskonały przykład na ożywioną działalność oświatową katolików, to ten zakon stworzył „szkoły, które na długi czas miały służyć za wzór tzw. szkół uczonych" ${ }^{\prime 3}$.

Bardziej wyważoną opinię o szkolnictwie jezuickim, uwzględniającą zarówno zalety, jak i wady ich pedagogiki, przekazywała swoim czytelnikom Maria Bielska. Do wad zaliczyła zbyt ścisłe przestrzeganie Ratio Studiorum, do zalet troskę o wykształcenie nauczycieli oraz o unowocześnienie metod nauczania.

Dość krytycznie, choć uwzględniając także niewątpliwe zalety pedagogii ignacjańskiej, pisał o jezuitach Stanisław Kot. Zwracał on uwagę czytelników na zakres i organizację szkolnictwa jezuickiego, które „rozwinęło się w organizację potężną imponującą rozmiarami, świadomością celu i umiejętnym doborem środków"35. Podkreślił, że wychowywali w duchu religijnym, pokory i bogobojności a ich system był wzorem dla innych zakonów. Stanisław Kot wyraźnie zaznaczał, że ,jezuici do końca swego istnienia (1773) pozostaną naczelną organizacją wychowawczą w całym katolicyzmie, przytłaczając inne ogromem swoim, ruchliwościa, doświadczeniem i wpływem" ${ }^{36}$. Zauważył jednak w edukacji jezuickiej skłonność do dewocji i osłabiania uczuć narodowych uczniów ${ }^{37}$. W jego ocenie tradycje Ratio Studiorum jako wciąż obecne $\mathrm{w}$ świadomości pedagogicznej narodów katolickich nie sprzyjają wprowadzaniu innowacji do szkół ${ }^{38}$. Jak podsumowywał krakowski historyk kultury: „W ogóle jezuici, nie uważając pracy szkolnej i wychowawczej za cel sam w sobie, lecz tylko za narzędzie do swych religijno-kościelnych celów, starali się całą wiedzę, dostępną dla przeciętnych umysłów, przedstawić jako zbiór ciekawostek językowych i literackich, resztę sobie rezerwowali" ${ }^{\prime 3}$.

\footnotetext{
32 A. Łuczkiewicz, dz. cyt., s. 142.

${ }^{33}$ W. Seredyński, dz. cyt., s. 66.

${ }^{34}$ F. Majchrowicz, dz. cyt., s. 109.

35 S. Kot, Zarys, s. 612.

36 Tenże, Historia, s. 179.

37 Tamże, s. 182-183.

38 Tamże, s. 183.

${ }^{39}$ Tamże, s. 187.
} 
Tak zróżnicowanych opinii nie odnajdujemy w przypadku prezentacji innych zakonów. Pozytywnie oceniano w podręcznikach chociażby edukację prowadzoną przez pijarów, którzy w przeciwieństwie do kosmopolityzmu jezuitów wprowadzali do szkół i trwale pielęgnowali pierwiastek narodowy, postawy obywatelskie i patriotyczne.

Jak wynika z powyższych analiz, w podręcznikach historii wychowania wiele miejsca zajmowały zagadnienia edukacji religijnej $\mathrm{w}$ prezentowaniu dziejów oświaty w epoce średniowiecza i renesansu. Nieco mniej uwagi poświęcano tym kwestiom przy ukazywaniu rozwoju szkolnictwa i wychowania w późniejszych okresach. Ograniczenie wpływów Kościoła na edukację i zmiany w pojmowaniu roli religii w życiu człowieka były różnie oceniane przez autorów podręczników. Jako przykład można podać tutaj Marię Bielską, która przechodząc do charakterystyki nowych prądów i koncepcji w wychowaniu XVIII wieku zaznaczyła pojawienie się tendencji do ograniczania roli religii w życiu człowieka poprzez deizm i ateizm. O jej stosunku do tych zjawisk najwymowniej świadczą te słowa: „Popularyzowanie wiedzy (encyklopedia Diderot) tak cenne, gdy jest oparte na gruncie religijnym i moralnym, tu zamiast oświecać, oślepiło tych biedaków, którzy z ciemności wyprowadzeni nie umieli odróżnić światła od ognia"40.

Obraz edukacji religijnej w Europie w wieku XVIII ogranicza się W większości opracowań do negatywnych opinii dotyczących braku wychowania religijnego w koncepcji pedagogicznej Jana Jakuba Rousseau. I tak Franciszek Majchrowicz zarzucił mu ,brak gruntu moralnego" ${ }^{41}$, lekceważenie wiary w Boga oraz ,pomiatanie wychowaniem religijnym”42. Także Stanisław Kot wskazywał, że brak edukacji religijnej do 15 roku życia propagowany przez Jana Jakuba Rousseau nie był możliwy do zaakceptowania „Z chrześcijańskiego punktu widzenia”"43. Z kolei ks. Józef Bielenin zaznaczał, że dzieło Emil zawierało zasadnicze błędy przeciwko wierze i obyczajom chrześcijańskim ${ }^{44}$. Podkreślał jednak, że szanując przywiązanie Polaków do wiary katolickiej autor ten powściagnął swoje „,bluźnierstwa religijne” w Uwagach nad rzadem polskim ${ }^{45}$.

Obraz polskiej edukacji religijnej XIII wieku to w podręcznikach przede wszystkim oświatowa działalność Stanisława Konarskiego, oparta na wzorach chrześcijańskich oraz ogólna reforma szkolnictwa pijarskiego. Poszcze-

\footnotetext{
${ }^{40}$ M. Bielska, dz. cyt., s. 105.

41 F. Majchrowicz, dz. cyt., s. 197.

42 Tamże, s. 202.

43 S. Kot, Historia, s. 365.

44 J. Bielenin, Historia, s. 385.

45 Tamże, s. 386.
} 
gólni autorzy wyraźnie zaznaczali, że ideał wychowawczy twórcy Collegium Nobilium polegał na moralnym udoskonaleniu człowieka a sam Stanisław Konarski, między innymi zdaniem Władysława Seredyńskiego, zajmował „chrześcijańsko humanitarne stanowisko w dziejach wychowania i oświecenia narodów" ${ }^{46}$. Przypisywano mu postawę chrześcijańską i humanitarną, która później cechować będzie także prace Komisji Edukacji Narodowej. Podkreślano, że potrafił on nie tylko teoretycznie definiować pojęcia i potrzeby edukacyjne, ale również realizować je w praktyce i zachęcać do tego innych. Zaznaczano, że choć naraził się w ten sposób na wrogie ataki, to jednocześnie zmobilizował inne zakony do przeprowadzenia reform w swoich szkołach. Przede wszystkim akcentowano, że zainspirował też świeckich do działań na rzecz szerzenia oświaty.

W podręcznikach nie zabrakło także wzmianek o wypracowanych przez Komisję Edukacji Narodowej zasadach wychowania religijno-moralnego opartego na wartościach chrześcijańskich. Ten aspekt w dorobku Komisji szczególnie eksponowali dwaj autorzy ks. Józef Bielenin i ks. Jan Tadeusz Peche. Jak podsumowywał Józef Bielenin: „Komisja edukacyjna unarodowiła szkołę, a przez to dźwignęła Ojczyznę z jej duchowego upadku. Rozwinąwszy działalność swą na gruncie wiary i religii narodu, chciała dla przyszłych jego przywódców i wychowawców być i przykładem, który naśladować i hasłem, pod którym innych do pracy nad odrodzeniem Ojczyzny zachęcać i wzywać mają" ${ }^{47}$. Natomiast Jan Tadeusz Peche doceniał szczególnie fakt, że nowoczesna pedagogika Komisji nie oznaczała jednocześnie negacji zasad chrześcijańskiej, głębokiej wiary i polskich tradycji narodowych ${ }^{48}$.

Stosunkowo niewiele miejsca poświęcały podręczniki edukacji religijnej w dobie zaborów. Na ich kartach odnaleźć można jedynie informacje o duchownych i zakonnikach zaangażowanych w ogólny rozwój oświaty, najczęściej wymieniane postaci to Hugo Kołłątaj, Grzegorz Piramowicz czy Jakub Falkowski. Jednocześnie w kilku publikacjach podkreślono dążenia Klementyny z Tańskich Hoffmanowej do nadania wychowaniu charakteru religijno-narodowego. Jedynie Władysław Seredyński, oceniając sytuację oświaty w Galicji przed rokiem 1848, zauważył, że „W tej ciężkiej a długiej dla narodu chwili, śmiało rzec można iż tylko [...] cnotliwemu i ludzkiemu duchowieństwu, w którego ręku spoczywał najbliższy dozór i współpraca w szkole zawdzięczać należy, że kraj nie popadł w zupełne na całym obszarze zdziczenie"49.

\footnotetext{
46 W. Seredyński, dz. cyt., s. 109.

47 J. Bielenin, Szkoły, s. 69.

48 J. T. Peche, dz. cyt., s. 331.

49 W. Seredyński, dz. cyt., s. 233.
} 
Jakie zatem możliwości poznania problematyki edukacji religijnej na przestrzeni wieków dawały polskie podręczniki historii wychowania okresu zaborów i II Rzeczypospolitej? Z przeprowadzonych tutaj analiz wynika, że najwięcej miejsca poświęcano tym zagadnieniom przy prezentacji dziejów wychowania w starożytności, średniowieczu i w epoce renesansu. Poszczególni autorzy ukazywali wpływ religii na kształtowanie się określonych wzorów i ideałów wychowawczych, rolę Kościoła jako propagatora i opiekuna oświaty oraz wpływ przełomów religijnych na edukację. Przybliżali także zasady funkcjonowania szkół prowadzonych przez duchownych i zakonników. Przy czym zaznaczyć należy, że szerzej omawiano jednak instytucje realizujące w praktyce edukację religijną niż jej podstawy teoretyczne czy ogólne założenie programowe.

Za charakterystyczny rys prezentacji edukacji religijnej w podręcznikach historii wychowania uznać można troskę wielu autorów, i to nie tylko duchownych, o zachowanie równowagi w prezentowaniu koncepcji i osiągnięć pedagogicznych katolików i protestantów. Wiąże się to z pewnością z wpływami założeń propagowanego w okresie zaborów wychowania narodowego oraz z silnym oddziaływaniem niemieckiej literatury historycznooświatowej na ziemiach zaboru austriackiego. Autorzy polskich podręczników starali się ukazywać czytelnikom niektóre tendencyjne opinie zawarte w tych publikacjach. Jednocześnie wyraźnie widoczna jest także tendencja, zwłaszcza u ks. Józefa Bielenina i Jana Tadeusza Peche, do oceniania europejskich koncepcji pedagogicznych pod kątem ich zgodności z założeniami katolicyzmu.

Na podkreślenie zasługuje także wyraźne wskazywanie religijnych podstaw koncepcji wychowania moralnego propagowanego w Polsce w XVIII wieku przez Stanisława Konarskiego i Komisję Edukacji Narodowej. Wpisywały się one w tendencję do ukazywania narodowych tradycji rodzimej oświaty opartej na kultywowaniu języka ojczystego, historii oraz przywiązania do katolicyzmu.

\section{Religious Education in Polish Textbooks on the History of Education from the 19th Century and the Beginning of the 20th Century} (Summary)

The aim of this paper is to show how religious education was portrayed in Polish textbooks on the history of education. The subject of the analysis are both the oldest publications of this kind, published in the second half of the 19th century 
and intended mainly for students of teachers' seminars in Galicia, as well as later publications, intended also for university students. The adopted time perspective allows the author to indicate the main directions of change in the textbooks on the subject; the oldest textbook examined in the paper comes from 1868, while the most recent of the analysed publications were published before the outbreak of the Second World War.

The issues taken up in the paper include both the scope within which the matter of religious education was considered in textbooks, as well as the attitude of individual authors towards religious education. Therefore, important here are not only issues concerning the selection of specific concepts, schools and educational activists propagating religious ideas in teaching and education, but also the form of their presentation. Crucial is also the question about the effect of various factors, e.g. the political situation or the development of historical and educational research, on the changes in the assessment of the religious education in its conceptual and practical aspect made by the authors of these studies. 